\title{
Effects of Precipitation and Livestock Grazing on Foliage Foraging Ants in a Chihuahuan Desert Grassland
}

\author{
Yosef Steinberger $^{1 *}$, Walt G. Whitford ${ }^{2}$ \\ ${ }^{1}$ The Mina and Everard Goodman Faculty of Life Sciences, Bar-Ilan University, Ramat Gan, Israel \\ ${ }^{2}$ USDA-ARS Jornada Experimental Range, Box 3 JER, New Mexico State University, Las Cruces, NM, USA \\ Email: *Yosef.Steinberger@biu.ac.il
}

How to cite this paper: Steinberger, Y. and Whitford, W.G. (2021) Effects of Precipitation and Livestock Grazing on Foliage Foraging Ants in a Chihuahuan Desert Grassland. Open Journal of Ecology, 11, 52-63. https://doi.org/10.4236/oje.2021.111005

Received: December 9, 2020

Accepted: January 10, 2021

Published: January 13, 2021

Copyright $\odot 2021$ by author(s) and Scientific Research Publishing Inc. This work is licensed under the Creative Commons Attribution International License (CC BY 4.0).

http://creativecommons.org/licenses/by/4.0/

\section{(c) (i) Open Access}

\begin{abstract}
We examined the relationship between seasonal livestock grazing (late summer and late winter) and the abundance of two ant species, Dorymyrmex insana and Forelius pruniosus, on three types of plants (mesquite shrubs, snakeweed sub-shrubs, and mixed grasses) dominated by black grama (Bouteloua eriopoda). Stocking rates were adjusted to remove $75 \%$ of the available forage. Since Chihuahuan Desert grasslands are not in transition to shrublands, the grasses and some herbaceous plants are the only available forage. We hypothesized that neither rainfall nor cattle grazing would affect the abundance of these ants on mesquite (Prosipis glandulosa) or snakeweed ( $\mathrm{Gu}$ tierrezia sarothrae). Linear regressions of monsoon rainfall on mesquite (Prosopis glandulosa) produced an $\mathrm{r}^{2}$ nearly equal to that with the annual precipitation. Monsoon rainfall on the evergreen sub-shrub, Gutierrezia sarothrae, resulted in June-July rainfall accounting for $47 \%-83 \%$ of the variation in densities of $D$. insana on snakeweed. The number of $D$. insana was more than double the number of $F$. pruinosus on grasses, mesquite, and snakeweed. There were significant reductions in the abundance of $F$. pruinosus on the grass in the grazed plots; each year the plots were grazed. There were no significant effects of grazing on the abundance of either of the ant species sampled from $G$. sarothrae canopies. There were significantly fewer $D$. insana on mesquite in summer grazed plots than on $P$. glandulosa in winter grazed and ungrazed plots in the second and third years of grazing. Pre-grazing effects were compromised by the high annual (more than double) precipitation.
\end{abstract}

\section{Keywords}

Grazing, Litter, Ants, Desert System 


\section{Introduction}

Selected species of ants recruit rapidly to a rich food source and may reduce the abundance of other species at that source [1] [2]. For example, the dolichoderine ant Forelius pruniosus usually displaces the formicine honey-pot ants (Myrmecocystus spp.) at food baits [3]. Interference competition should be high where densities of ant colonies are high. Two species of the dolichoderine ant, Dorymyrmex insana and Forelius pruinosus, are the most abundant species in most plant communities in the northern Chihuahuan Desert [4]. Both species are widely distributed in the southern Chihuahuan Desert and south into Mexico [5]. Both Dorymyrmex and Forelius are absent or occur at low colony abundance in the Great Basin. Liquid feeding ants are not abundant in winter precipitation areas where snowfall is prevalent and much of the precipitation is in the form of snow. The effects of livestock grazing on vegetation and soils have been well documented [4] [6] [7]. In Nash et al.'s (2004) [8] study in the Mojave Desert, with winter rainfall, both $D$. insana and $F$. pruinosus were abundant and affected by livestock grazing, especially at the most heavily grazed sites. Specifically, $D$. insana was found at each of the six sites sampled, whereas $F$. pruinosus was found only at four. The ant species similarity index decreased from $68 \%$ to $53 \%$ with distance from a water source [8].

On grazed sites in southeastern Arizona grasslands, beetle communities were more rich, flies more diverse, and Hymenoptera (including ants) were more rich and diverse when compared to grazed sites [9]. That result is very different from the one obtained in grasslands within the historic range of bison. Studies in the historic range of bison reported little response of the insect community to livestock grazing [10] [11]. In those studies, grasshoppers and other insects were either positively influenced or not affected by livestock grazing. DeBano (2006) [9] hypothesized that the effect of livestock grazing on insects would be the greatest where grasslands had evolved without large herbivores. In Chihuahuan Desert grasslands, there were few, if any, bison. The grasslands are composed of warm-season grasses like Bouteloua eriopoda (black grama), Sporobolus spp. (dropseeds), and Aristida spp. (three awns), whereas the grasslands with large herds of bison were primarily limited to the short grass prairies and mid-height and tall grasses of the plains of North America. We hypothesized that liquid feeding ants would respond to livestock grazing because the flora and fauna had not evolved with large herbivores.

Two of the most abundant and spatially widespread ant species in the northern Chihuahuan Desert are Dorymyrmex (Conomyrma) insana and Forelius pruinosus [12]. D. insana nests were found to be concentrated around the base of mesquite (Prosopis glandulosa) shrubs, while the spatial distribution of $F$. pruinosus nests was random [13] [14]. These two species forage in the plant canopies for liquids (homopteran honeydew and plant exudates) and insect carrion. $D$. insana is an interference competitor with $F$. pruinosus on particularly rich food sources [2]. The quality of plant canopies as habitat for homopterans 
and/or as sources of exudates varies with soil water and nutrients [15] [16]. Fire has the effect of increasing soil erosion and run-off [17]. As part of an experiment designed to examine the effects of multiple stressors on a desert grassland ecosystem, we examined variations in the abundance of $D$. insana and F. pruinosus on three different plant types: perennial grasses, evergreen sub-shrubs (Gutierrezia sarothrae), and winter deciduous mesquite ( $P$. glandulosa) shrubs. We hypothesized that the abundance of these ants on grasses would decrease as plant quality declined with drought and/or livestock grazing.

\section{Methods}

The study was conducted at an experimental site (elevation $1300 \mathrm{~m}$ ) located 8 $\mathrm{km}$ west of the USDA-ARS Jornada Experimental Range Headquarters $\left(32.45^{\circ} \mathrm{N}\right.$, $106.49^{\circ} \mathrm{W}$ ) approximately $58 \mathrm{~km}$ NNE of Las Cruces, New Mexico. Eighteen, 0.5-hectare plots enclosed by three-strand barbed wire fencing were established in 1993 on an ecotone between black grama (Bouteloua eriopoda) grassland and mesquite (Prosopis glandulosa) coppice dunes. There were no spaces between fences and the sampling was conducted in the center of the plots. Six plots were grazed in winter (February), six plots were grazed in summer (August), and six plots were not grazed. Mesquite shrubs were removed from 3 plots of each grazing treatment, and re-sprouts were treated with Roundup ${ }^{\mathrm{TM}}$ for the duration of the study. There were nine plots with mesquite shrubs from which $P$. glandulosa were sampled for the two species of ants. Plots were grazed for three consecutive years. Stocking rates were adjusted to achieve removal of approximately $75 \%$ of the available forage. Plots were stocked with between 20 to 40 yearling cows for 24 to 30 hours, resulting in the removal of between $65 \%$ and $80 \%$ of the estimated available forage. Ants foraging in the foliage were sampled in grasses (12 plots-summer grazed and winter grazed). We also selected snakeweed, Gutierrezia sarothrae, an evergreen sub-shrub that is not eaten by livestock.

Each plot was subdivided into 102 subplots. Fifteen subplots were selected at random for each plot for sampling ants foraging in the foliage. Ants on mesquite shrubs were collected by placing a net below the canopy and beating the foliage above the net three times with a rod to dislodge the ants. Two sides of each mesquite shrub were sampled on each subplot. Five snakeweed plants, $G$. sarothrae, were sampled in each subplot by a single sweep of the net through the canopy. Grasses were sampled by taking ten sweeps through the grass canopies while walking on a diagonal across the selected subplots. The ants and other insects were transferred from the net into plastic ziplock bags and stored in a freezer in the laboratory. Ants were separated from the other insects using an Olympus zoom stereomicroscope and identified to species. Data on abundance of ant species in the foliage among years and treatments were subjected to a three-way factorial analysis of variance with the Duncan test used for multiple pairwise comparisons of treatment effects using the StatView statistical package. Normality of data sets was checked with the Kolmogorov-Smirnov test. The ab- 
undance of each ant species foraging in the canopy foliage in relationship to rainfall was examined by linear regression as a function of monsoon precipitation (July through September). Precipitation was recorded at a rain gauge on the watershed that terminates in a large dry lake, one rain gauge near the mesquite coppice dunes, and rain gauges at the Jornada tobosa dry lake and the most distant grassland [18].

\section{Results}

The relationship between annual precipitation and monsoon (July-September) precipitation was compromised by the high precipitation of the year before setting up the grazing experiment and removal of mesquite from half the plots. The total precipitation in the prior year was $404.5 \mathrm{~mm}$, while the monsoon rainfall was $89.4 \mathrm{~mm}$. That annual precipitation was nearly double the average annual precipitation of $220 \mathrm{~mm}$. The effect of extremely large precipitation on the Chihuahuan Desert grasslands affects the following year's productivity by increasing the biomass of the grasses. That increase in biomass of grasses leads to legacies in terms of plant biomass and soil moisture. Legacies in arid regions are a function of three variables: 1) the magnitude of the historical phenomenon, 2) the time elapsed since the occurrence of the phenomenon, and 3) the sensitivity of the ecological-soil-geomorphic system to change.

The regressions of Dorymyrmex insana numbers on mesquite (Prosopis glandulosa) were almost equal in terms of $\mathrm{r}^{2}$ for both annual rainfall and monsoon rainfall, with the monsoon rainfall $r^{2}$ slightly larger than the $r^{2}$ for annual rainfall: annual rainfall $\mathrm{r}^{2}$ summer grazed -0.09 , winter grazed -0.63 , and not grazed, control-0.38 (Figure 1). The pattern was very different on snakeweed (Gutierrezia sarothrae): regressions with the monsoon rainfall yielded $\mathrm{r}^{2}$ less than the $\mathrm{r}^{2}$ recorded for annual rainfall. The $\mathrm{r}^{2}$ for annual rainfall and $D$. insana were: summer grazed -0.47 , winter grazed -0.83 , and not grazed -0.61 . The $\mathrm{r}^{2}$ for annual rainfall and $F$. pruinosus were: summer grazed -0.30 , winter grazed -0.25 , and not grazed-0.10 (Figure 2).

The pattern of $D$. insana and $F$. pruinosus on grasses was similar to the pattern on snakeweed. The $\mathrm{r}^{2}$ of the regressions of annual rainfall and numbers of ants were: $D$. insana-summer grazed -0.82 , winter grazed -0.73 , and not grazed -0.78 . The $\mathrm{r}^{2}$ of the regressions relating annual rainfall to the numbers of $F$. pruinosus were: summer grazed -0.21 , winter grazed -0.47 , and not grazed -0.012 . Because there were no effects of shrub removal on the abundance of ants foraging in the vegetation foliage, shrub removal was eliminated as a variable affecting the behavior of these ants (Figure 3).

There was a significant relationship between June-July rainfall and the densities of $D$. insana on grass foliage in grazed and ungrazed plots (Figure 2). There was little or no relationship between June-July rainfall and densities of $F$. pruinosus foraging in grass foliage or snakeweed canopies (Figure 2 \& Figure 3 ). There was no relationship between June-July rainfall and abundance of $D$. insana on snakeweed foliage or mesquite foliage. June-July rainfall accounted for 

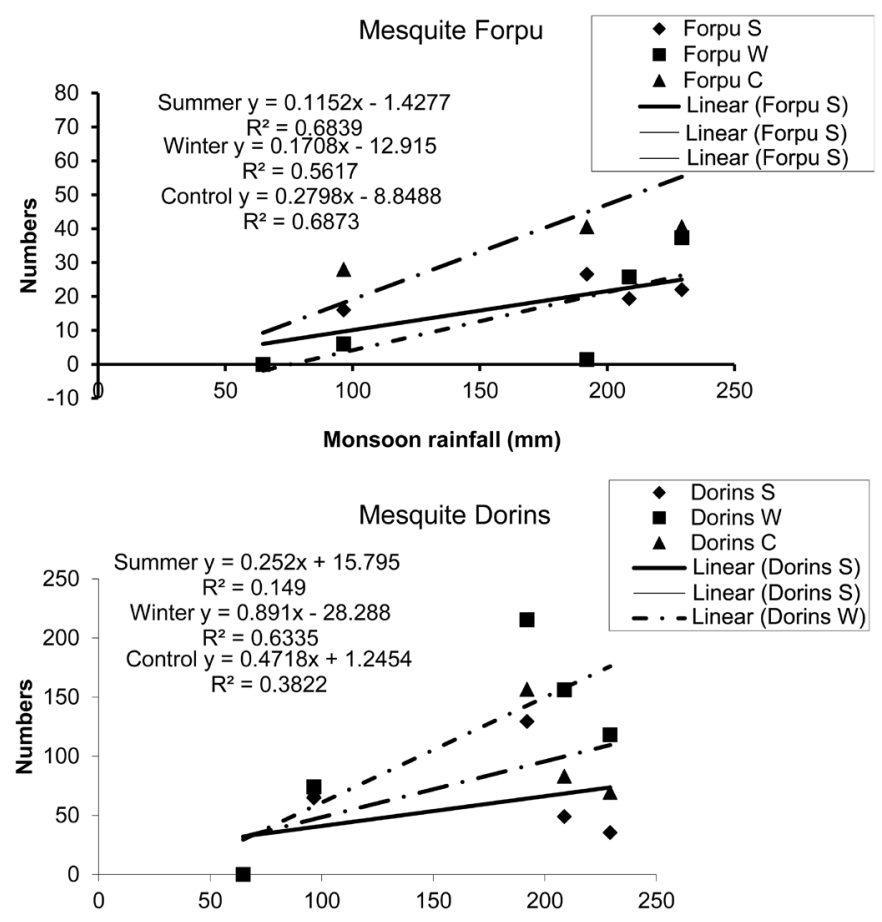

Figure 1. Linear regressions of monsoon (July through September) precipitation and numbers of Dorymyrmex insana (Dorins) and Forelius pruinosus (Forpru) on mesquite: black grama grass (Bouteloua eriopoda), Sporobolus spp., and Aristida spp.
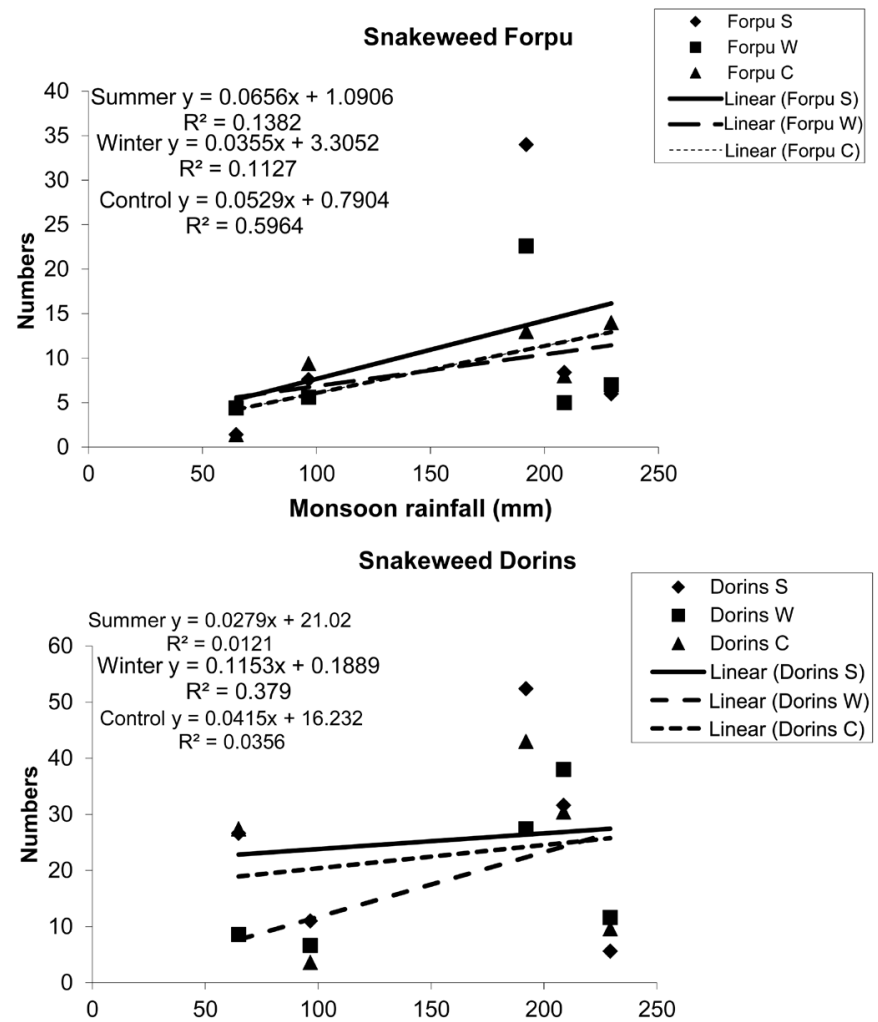

Figure 2. Linear regressions of monsoon (July through September) precipitation and numbers of Dorymyrmex insana (Dorins) and Forelius pruinosus (Forpru) on snakeweed: black grama grass (Bouteloua eriopoda), Sporobolus spp., and Aristida spp. 

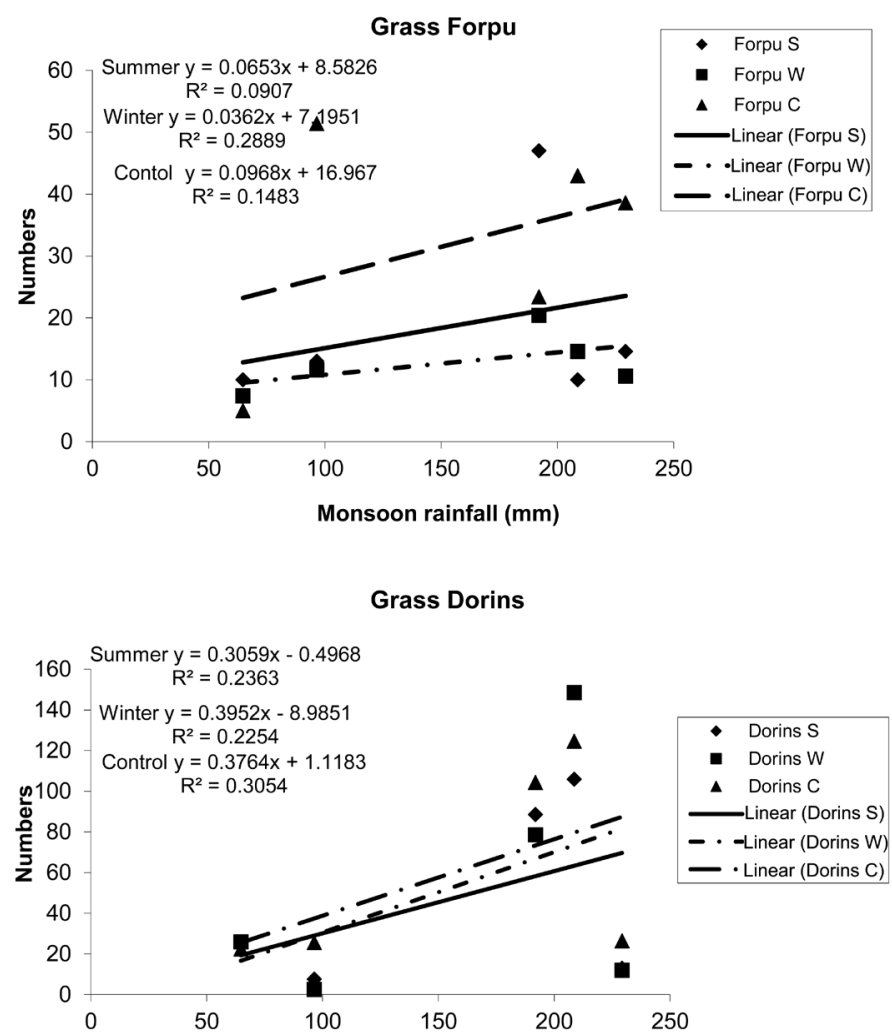

Figure 3. Linear regressions of monsoon (July through September) precipitation and numbers of Dorymyrmex insana (Dorins) and Forelius pruinosus (Forpru) on grass: black grama grass (Bouteloua eriopoda), Sporobolus spp., and Aristida spp.

between $47 \%$ and $83 \%$ of the variation in densities of $D$. insana foraging in snakeweed canopies. There was no relationship between June-July rainfall and the abundance of $F$. pruinosus in grass, mesquite, or snakeweed foliage.

There was a marginally significant reduction in the abundance of $D$. insana on grass $\left(\mathrm{F}_{2,15}=3.2, \mathrm{p}<0.06\right)$ on grazed plots in the second year of grazing but no significant effects of shrub removal or grazing in any of the other years. There were significant reductions in the abundance of $F$. pruinosus on grass on the grazed plots each year the plots were grazed (Table 1, Figure 4). There were no significant effects of grazing on the abundance of either of the ant species sampled from $G$. sarothrae canopies. There were significantly fewer $D$. insana on mesquite in summer grazed plots than on $P$. glandulosa in winter grazed and ungrazed plots in the second and third years of grazing (Table 2, Figure 4).

When large numbers of cattle grazed in order to remove $75 \%$ of the available forage, the biomass of grasses and some forbs was reduced. However, that was not the only effect of grazing. Grazing by cattle results in the loss of microtopography associated with mounds around the base of grass tussocks [19]. Not only did the action of the hoofs of livestock compact the soil but also the changes in microtopography affected water infiltration spatially. Despite these changes, the only difference in the effects of grazing on the ants was recorded in the second year of grazing. 

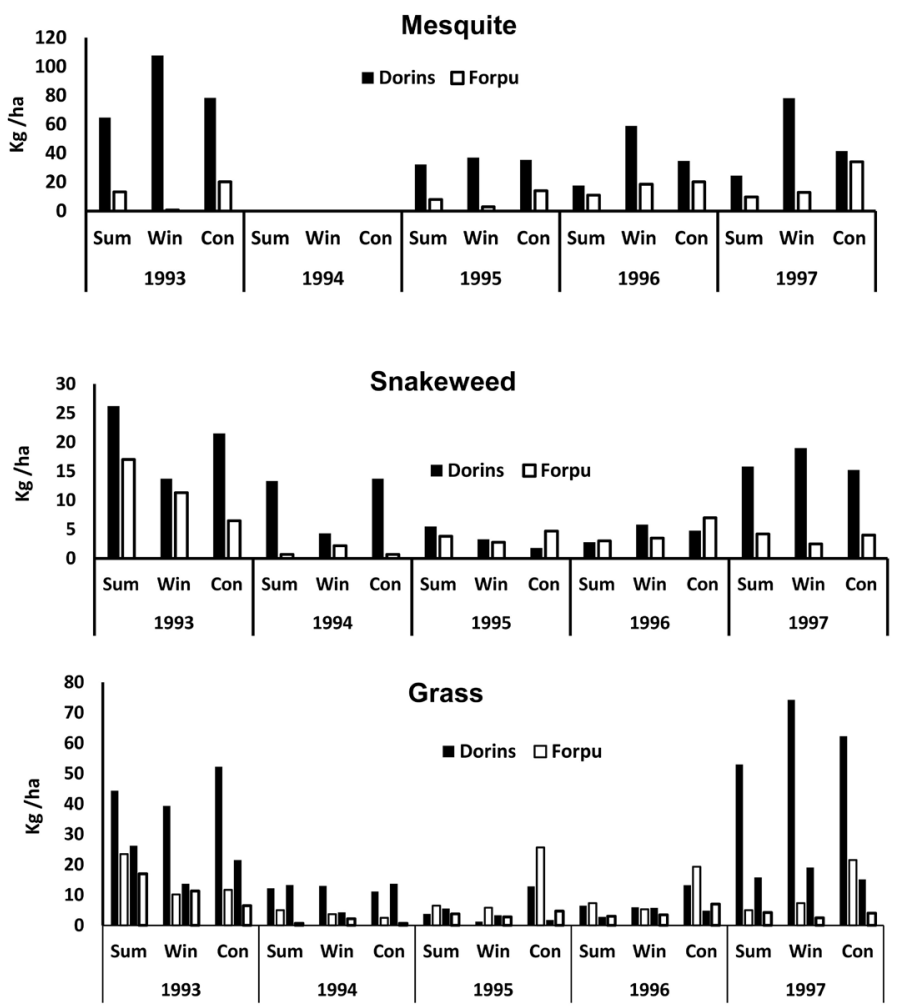

\section{Sampling periond}

Figure 4. Total amount of goliage (Kg/ha) at the Dorymyrmex insana and Forelius pruinosus ants nests at mesquite, snakeweed, and mesquite sites between 1993-1997.

Table 1. Analysis of variance on the effects of livestock grazing on the abundance of Forelius pruinosus on grass foliage.

\begin{tabular}{ccc}
\hline Year & $\mathrm{F}_{2,15}$ & $\mathrm{p}$ \\
\hline Grazed Year 1 & 6.6 & $<0.01$ \\
Grazed Year 2 & 7.0 & $<0.01$ \\
Grazed Year 3 & 4.0 & $<0.04$ \\
\hline
\end{tabular}

Table 2. Average numbers of Dorymyrmex insana ( $D$. insana) and Forelius pruinosus (For. pru.) \pm standard deviation with the results of the analysis of variance indicated by a and $b$. Numbers followed by the same letter are not significantly different at the $\mathrm{p}<0.05$ level.

\begin{tabular}{ccccccc}
\hline Plants & summer & winter & control & summer & winter & control \\
\hline Sampled & D. insana & D. insana & D. insana & F. pruinosus. & F. pruinosus & F. pruinosus. \\
\hline Grasses & $50.0 \pm 46.4 \mathrm{a}$ & $66.0 \pm 68.0 \mathrm{a}$ & $56.0 \pm 55.1 \mathrm{a}$ & $16.6 \pm 15.9 \mathrm{a}$ & $10.0 \pm 3.1 \mathrm{a}$ & $29.8 \pm 17.8 \mathrm{a}$ \\
Mesquite & $56.3 \pm 30.4 \mathrm{a}$ & $130.0 \pm 72.6 \mathrm{a}$ & $77.0 \pm 28.7 \mathrm{a}$ & $16.0 \pm 1.4 \mathrm{a}$ & $6.3 \pm 9.5 \mathrm{~b}$ & $41.3 \pm 16.5 \mathrm{a}$ \\
Snakeweed & $24.2 \pm 18.5 \mathrm{a}$ & $17.0 \pm 12.6 \mathrm{a}$ & $20.0 \pm 14.3 \mathrm{a}$ & $11.0 \pm 13.6 \mathrm{a}$ & $8.6 \pm 9.2 \mathrm{a}$ & $8.8 \pm 6.5 \mathrm{a}$ \\
\hline
\end{tabular}

\section{Discussion}

A study in the Great Basin in Idaho reported that rangeland sites in poor condi- 
tion had lower ant species richness. Range condition is the status of arid rangelands determined by the cover of forage and patches of bare soil. In Idaho, species richness and relative abundances of several groups of ant species were significantly related to bare patch size and parameters for cover or species richness for several vegetation types [14]. However, there were no significant differences with liquid feeding ants and/or homopteran tenders in Idaho or Utah. The Great Basin does not support many species of liquid feeding ants, while in the Chihuahuan Desert, the two species studied here are the most numerous colonies of ants. This may account for the differences reported between the Great Basin and the Chihuahuan Desert [14].

Medium-legacies of years to decades in length include the negative effect of drought, even after the drought is over, or the positive effect of an extremely large rain event after the event has occurred. For example, in grasses, tiller density is determined by the precipitation and production of the previous year which in turn affects a desert grasslands' ability to utilize available water [20]. However, mean annual precipitation is not a good predictor of temporal variability in grass productivity. One large component of the temporal variability is rainfall legacy. Legacies occur when there are lags in the response of ecosystems to changes in water availability. Legacies are the effect of drought after the drought has subsided, or the effect of an extremely wet period after it has occurred [21]. A legacy may be quantified as the difference between the observed annual productivity and the expected annual productivity, which is estimated using the actual precipitation and temporal precipitation-productivity relationships for a site. The legacy of $404.5 \mathrm{~mm}$ of precipitation the year before the experiment was set up resulted in high grass production and large numbers of liquid-feeding ants on the grasses. The number of $D$. insana in the first year before grazing was 810 compared to 218 during the second year before grazing. The number of $F$. pruinosus on the grasses in the first year before grazing was 272 compared to 67 in the second year before grazing. The differences in numbers of liquid-feeding ants (Table 3 ) on the grasses are a function of the legacy effect of the high precipitation the year before the experiment was set up.

Some grasses are taken by grazers only when green, while other grasses are consumed either as green forage or as senescent material [22]. Most plant species that are grazed are negatively impacted by grazing [23]. In our study, both ant species were affected by the remaining grasses after either summer or winter grazing. The numbers of $D$. insana were $(3-5) \times$ larger than the numbers of $F$. pruinosus on grasses, supporting the conclusion of Van Zee et al. (1997) that there is a competition between these species with the smaller $F$. pruinosus dominated by interference competition by the larger $D$. insana.

In one study, the abundances of $F$. pruinosus and $D$. insana were higher in grazed grassland than in ungrazed grassland [13]. In our study, intense, short-duration grazing by cattle resulted in a reduction in the numbers of $F$. pruinosus foraging in grass foliage but had little effect on the numbers of $D$. insana foraging in grass foliage. Livestock grazing can have an effect on the quality 
Table 3. Mean numbers of the two studied liquid-feeding ants on the three plant species that dominate the ecotone between grassland and Mesquite dunes with Duncan grouping indicated by letters $a$ and $b$. Means with the same letter are not significantly different.

\begin{tabular}{ccc}
\hline Plant Species-season of grazing & Mean & Number of Samples \\
\hline Mesquite Control & $50.13 \mathrm{a}$ & 8 \\
Grass Control & $42.9 \mathrm{a}, \mathrm{b}$ & 10 \\
Snakeweed Control & $14.4 \mathrm{~b}$ & 10 \\
Mesquite Winter & $68.13 \mathrm{a}$ & 10 \\
Grass Winter & $38.1 \mathrm{a}, \mathrm{b}$ & 10 \\
Snakeweed Winter & $12.8 \mathrm{a}$ & 10 \\
Mesquite Summer & $36.13 \mathrm{a}$ & 8 \\
Grass Summer & $33.3 \mathrm{a}$ & 10 \\
Snakeweed Summer & $17.6 \mathrm{a}$ & 10 \\
\hline
\end{tabular}

of grass foliage and also on the abundance and diversity of homopterans living on the foliage [24]. Since both ant species tend Homoptera and collect honey-dew from these insects, the differences in the responses of $D$. insana and $F$. pruinosus to livestock grazing may result from an indirect effect of livestock grazing on the abundance and species composition of the Homoptera on the grass foliage

Intensive grazing by cattle not only reduces the available forage by $75 \%$ but also results in leveling of the microtopography of the grass tussocks that accumulate soil around the base of the grass [19]. There were similar densities of both of the species of liquid-feeding ants during the first two years after grazing [13] [25]. Changes in microtopography did not seem to affect the distribution of the ant colonies.

Monsoon rains for almost two months allowed the recovery of winter grazed grasses to the biomass and quality of the grasses somewhat close to the pre-grazing condition. Insects were sampled after the summer grazed plots had been grazed by livestock, resulting in the removal of most of the biomass of grasses. Neither mesquite nor snakeweed is consumed by livestock. Differences in abundances of $D$. insana and $F$. pruinosus on grasses can be attributed to interference competition.

One surprising result was the effect of winter grazing on the liquid-feeding ants on $P$. glandulosa, in which the abundance of $D$. insana on mesquite was more than $20 \times$ the numbers of $F$. pruinosus on those shrubs. It is apparent that the effect of winter grazing when mesquite is fully leafed supports sufficient populations of homopterans for liquid-feeding ants. That combination of liquid-feeding ants led to intense displacement competition of $F$. pruinosus by $D$. insana, which confirms the conclusion that these species compete for rich resources [2]. Mesquite was sampled at the same time as the grasses and snakeweed. However, on snakeweed, there were no differences in abundance between 
$D$. insana and F. pruinosus. Since snakeweed is toxic to livestock, we did not expect any differences between these species of liquid-feeding ants with winter or summer grazing on Gutierrezia sarothrae.

Since Chihuahuan Desert grasslands and southeastern Arizona grasslands were isolated from herds of large herbivores (bison), we predicted that there would be large differences in grazed and ungrazed grasslands. In a summer rainfall desert, many of the grasses and shrubs were flowering when sampled in late August. There are many insects including homopterans that are attracted to flowers and that may be one reason for differences in the grazing effects on the ants.

\section{Conclusion}

We can conclude from this study that the differences among grazing treatments for liquid feeding ants were the greatest on grasses that were grazed, and the season of grazing had essentially no effect on the ants. However, the sites with winter grazing on mesquite had higher numbers of $D$. insana than of $F$. pruinosus, indicating the competitive exclusion of the smaller $F$. pruinosus. The regressions demonstrate that there was an interaction between annual and monsoon precipitation and the numbers of both species of ants on the plant species in this study. The Great Plains were populated by huge numbers of bison that were a feature of that region for millennia, and grazing had a positive effect on some insects [22]. There were few, if any, bison in the Chihuahuan Desert. The ant communities in the Chihuahuan Desert and Mojave Desert evolved in the absence of large herbivores, which probably accounts for the effects of livestock grazing on liquid-feeding ants.

\section{Acknowledgements}

We wish to thank Ms. Yael Laura for her useful comments.

\section{Author Contribution}

The authors contributed equally to this work.

\section{Conflicts of Interest}

The authors declare no conflicts of interest regarding the publication of this paper.

\section{References}

[1] Holldobler, B. and Wilson, E.O. (1990) The Ants. Belnap Press, Cambridge. https://doi.org/10.1007/978-3-662-10306-7

[2] Van Zee, J.W., Whitford, W.G. and Smith, W.E. (1997) Mutual Exclusion by Dolichoderine Ants on a Rich Food Source. The Southwestern Naturalist, 42, 229-231.

[3] Holldobler, B. (1982) Interference Strategy of Iridomyrmex pruinosum (Hymenoptera: Formicidae) during Foraging. Oecologia, 52, 208-213.

https://doi.org/10.1007/BF00363838 
[4] Whitford, W.G. (1997) Desertification and Animal Biodiversity in the Desert Grasslands of North America. Journal of Arid Environments, 37, 709-720. https://doi.org/10.1006/jare.1997.0313

[5] Mackay, W. and Mackay, E. (2002) The Ants of New Mexico (Hymenoptera: Formicidae) Lewiston. Edwin Mellen Press, New York, 400 p.

[6] Marrs, R.H., Rizand, A. and Harrison, A.F. (1989) The Effects of Removing Sheep Grazing on Soil Chemistry Above-Ground Nutrient Distribution, and Selected Aspects of Soil Fertility in Long-Term Experiments at Moore House National Nature Reserve. Journal of Applied Ecology, 26, 647-661. https://doi.org/10.2307/2404089

[7] National Research Council (1994) Rangeland Health: New Methods to Classify, Inventory, and Monitor Rangelands. National Academy Press, Washington DC.

[8] Nash, M.S., Bradford, D.F., Franson, S.E., Neale, A.C., Whitford, W.G. and Heggem, D.T. (2004) Livestock Grazing Effects on Ant Communities in the Eastern Mojave Desert, USA. Ecological Indicators, 4, 199-213. https://doi.org/10.1016/j.ecolind.2004.03.004

[9] DeBano, S.J. (2006) Effects of Livestock Grazing on Aboveground Insect Communities in Semi-Arid Grasslands of Southeastern Arizona. Biodiversity and Conservation, 15, 2547-2564. https://doi.org/10.1007/s10531-005-2786-9

[10] Miller, R.H. and Onsager, J.H. (1991) Grasshopper (Orthoptera: Acrididae) and Plant Relationships under Different Grazing Intensities. Environmental Entomology, 20, 807-814. https://doi.org/10.1093/ee/20.3.807

[11] Welch, J.L., Redak, R. and Krondratieff, B.C. (1991) Effect of Cattle Grazing on the Density and Species of Grasshoppers (Orthoptera: Acrididae) of the Central Plains Experiment Range, Colorado: A Reassessment of Two Decades. Journal of the Kansas Entomological Society, 64, 337-343.

[12] Whitford, W.G. and Kay, F.R. (1999) Bioperturbation by Mammals in Deserts: A Review. Journal of Arid Environments, 41, 203-230. https://doi.org/10.1006/jare.1998.0482

[13] Nash, M.S., Whitford, W.G., Van Zee, J. and Havstad, K.M. (2000) Ant (Hymenoptera: Formicidae) Responses to Environmental Stressors in the Northern Chihuahuan Desert. Environmental Entomology, 29, 200-206. https://doi.org/10.1093/ee/29.2.200

[14] Nash, M.S., Whitford, W.G., Bradford, D.F., Franson, S.E., Neale, A.C. and Heggem, D.T. (2001) Ant Communities and Livestock Grazing in the Great Basin, U.S.A. Journal of Arid Environments, 49, 695-710.

https://doi.org/10.1006/jare.2001.0824

[15] Lightfoot, D.C. and Whitford, W.G. (1989) Interplant Variation in Creosotebush Foliage Characteristics and Canopy Arthropods. Oecologia, 81, 166-175. https://doi.org/10.1007/BF00379801

[16] Lightfoot, D.C. and Whitford, W.G. (1987) Variation in Numbers of Insects in Desert Shrubs: Is Nitrogen a Factor? Ecology, 68, 547-557. https://doi.org/10.2307/1938460

[17] Neary, D.G., Ryan, K.C. and DeBano, L.F. (2005) Wildland Fire in Ecosystems: Effect of Fire on Soils and Water. General Technical Report RMRS-GTR-42 Volume 4, U.S. Department of Agriculture Forest Service, Rocky Mountain Research Station, Ogden, 53-71. https://doi.org/10.2737/RMRS-GTR-42-V4

[18] Havstad, M.K., Juenneke, L.F. and Schlesinger, W.H. (2006) Structure and Function of a Chihuahuan Desert Ecosystem: The Jornada Basin Long-Term Ecological Re- 
search Site. LTER Pub. Oxford University Press, Oxford, 465. https://doi.org/10.1093/oso/9780195117769.001.0001

[19] Nash, M.S., Jackson, E. and Whitford, W.G. (2003) Soil Microtopography on Grazing Gradients in Chihuahuan Desert Grasslands. Journal of Arid Environments, 55, 181-192. https://doi.org/10.1016/S0140-1963(02)00251-3

[20] Monger, C., Sala, O.E., Duniway, M.C., Goldfus, H., Meir, I.A., Poch, R.M., Throop, H.L. and Vivoni, E.R. (2015) Legacy Effects in Linked Ecological-Soil-Geomorphic Systems of Drylands. Frontiers in Ecology and the Environment, 11, 13-19. https://doi.org/10.1890/140269

[21] Sala, O.E., Gherardi, L.A., Reichmann, L., Jobbagy, E. and Peters, D. (2012) Legacies of Precipitation Fluctuations on Primary Production: Theory and Data Synthesis. Philosophical Transactions of the Royal Society B, 367, 3135-3144.

https://doi.org/10.1098/rstb.2011.0347

[22] Coppock, D.L., Detling, J.K., Ellis, J.E. and Dyer, M.I. (1983) Plant-Herbivore Interactions in a North American Mixed-Grass Prairie. I. Effects of Black-Tailed Prairie Dogs on Intraseasonal Above-Ground Plant Biomass and Nutrient Dynamics and Plant Species Diversity. Oecologia, 56, 1-9. https://doi.org/10.1007/BF00378210

[23] Belsky, A.J. (1986) Does Herbivory Benefit Plants? A Review of the Evidence. The American Naturalist, 127, 870-892. https://doi.org/10.1086/284531

[24] Forbes, G.S., Van Zee, J.W., Smith, W. and Whitford, W.G. (2005) Desert Grassland Canopy Arthropod Species Richness: Temporal Patterns and Effects of Short-Duration Livestock Grazing. Journal of Arid Environments, 60, 627-646.

https://doi.org/10.1016/j.jaridenv.2004.07.004

[25] Nash, M.S. and Whitford, W.G. (2001) Ants as Biological Indicators for Monitoring Changes in Arid Environments: Lessons for Monitoring Protected Areas. In: Research and Management Options for Protected Areas, Proceedings of the First International Symposium and Workshop on Arid Zone Environments, Environmental Research and Wildlife Development Agency, Abu Dhabi, 105-121. 